\title{
A Case Report of Urusthambha Vyadhi
}

\author{
Case Report
}

\section{Dandekar Niraj Prakash ${ }^{*}$, Metkar Kranti²}

1. PG.scholar, 2. Associate professor \& HOD, Sharir Rachana Vibhag, YMT Ayurvedic Medical College, Kharghar

\begin{abstract}
Ayurved is the science of good long health and vitality. All possible vyadhis (disease) and their treatments classified under vata, pitta and kapha (tridosha) types. There have been mentioned 80 types of vata vyadhis (type of diseases) as per classical texts of ayurved. Uruthambha vyadhi (disease) is the type of vata vyadhi explained by acharya charak separately in Charak samhita other than mentioned 80 types. Urusthambha is caused due to avrodh (obstruction) of vata (type of dosha) by aama (indigested food) and meda dhatu (fat). It obstructs the natural karya (function) of vata in urupradesh (femoral region) due to which the patient has restricted or no movements of thighs. Hence it's the avran (covering) of aama \& meda dhatu to prakruta vata (normal vata)which produces difficulty in walking along with symptom as sthambha (stiffness) in uru Pradesh (thigh region) and hence known as urusthambha. Urustambha cases are very uncommonly seen and diagnosed in routine clinical practice and hence we thought to present the case which diagnosed \& successfully treated with only ayurveda. A male patient aged 39 yrs was reported for OPD by us at Shree gajanan ayurvedic chikitsalay and panchakarma centre, panvel, navi mumbai, Maharashtra (Registration no- 2166) with complaints of difficulty in walking with extreme pain and stiffness in uru pradesh (thigh region). We diagnosed and treated for urusthambha with classical treatment mentioned as per charak samhita (ayurvedic text) and was recovered completely after the regular treatment. Patient showed progressive improvement with complete cure in the period of 1 year \& 2 months with abhyantara (internal) and bahya chikitsa (external treatment).
\end{abstract}

Key Words: Avrutta vata, Vata vyadhi, Thigh stiffness, Jala chankraman, Thigh pain, Stambha.

\section{Introduction}

Vata vyadhi are commonly seen in society as vata is the main among tridosha which facilitates all actions in body. Ayurved also explains that 80 types of vata vyadhis occur in patients. But in all types of vata vyadhis urusthambha vyadhi is not commonly seen in day to day life. Hence charak acharya has mentioned separate explanation for urustambha vyadhi.

Urusthambha vyadhi described by Acharya Charak in Charak samhita sutrasthana

Literary meaning of word urusthambha is uru $($ thigh $)+$ stambha $($ column $)=$ urustambha $(3)$

Urustambha is the condition in which patient's thigh become painful, numbness and immobile as a column or a pillar. Its is the only type of vata vyadhi (type if disease classification as per ayurved) in which panchakrama (type of treatment procedure) doesn't work at all as stated by acharya charak in charak samhita chikitsasthana.

Hetu (causes) associated with urusthambha vyadhi in following case which match the classical picture are as follows-

* Corresponding Author:

Dandekar Niraj Prakash

PG Scholar, Sharir Rachana Vibhag,

YMT Ayurvedic Medical College, Kharghar

Email Id: niraj.dan@gmail.com
1. Snigdha (slimy), ushna (heat), laghu (light), shita (cold in potency/nature) padartha sevan (consumption of food product) repeatedly before digestion of previous consumed food.

2. Drava (liquidity), shushkata (dryness), dadhi sevan (curd), milk, mamsa sevan (meat consuming) every mentioned food product excess of intake is done by patient than required.

3. Pisthanna ( rice, moong, horse gram, wheat \& sura i.e. madira sevan).

4. Diwaswaap (sleeping in day times).

5. Atilanghan (not eating even if hunger due to work i.e. kshudha vegadharan)

6. Adhyashan (munching snacks even after food is taken).

7. Atishram (over exertion i.e.exertion beyond capacity)

8. Bhaya (afraid of situations).

9. Vegvidharan (obstructing or holding the natural urges and hunger).

\footnotetext{
Aims \& objectives

To estimate the efficacy of ayurved therapy in management of urustambha.
} 


\section{Materials \& methods}

\begin{tabular}{|c|c|}
\hline Type of study & $\begin{array}{l}\text { Single observational case without } \\
\text { control group }\end{array}$ \\
\hline Study centre & $\begin{array}{l}\text { Shree Gajanan Ayurvedic Chikitsalay } \\
\text { and Panchakarma centre, Panvel } \\
\text { 410206, Navi Mumbai, Maharashtra }\end{array}$ \\
\hline Medicines used & $\begin{array}{l}\text { Musta choorna, Lodhra, Pippali, } \\
\text { Pippalimoola, Devdaru, Medopachak } \\
\text { (ash.hruday), Shilajeet vati, } \\
\text { mahayogaraaj guggul, Brhat vaat } \\
\text { chintamani rasa, shankha vati, } \\
\text { Gandharvaharitaki choorna. } \\
\text { Procedure for administration of } \\
\text { medicine-All medicines mentioned } \\
\text { above are powdered and mixed } \\
\text { together in required amount and dose } \\
\text { is given thrice from the total amount } \\
\text { of medicines per day. }\end{array}$ \\
\hline $\begin{array}{l}\text { Administration } \\
\text { route for } \\
\text { medicines }\end{array}$ & Oral route of administration \\
\hline $\begin{array}{l}\text { Valuka pottali } \\
\text { swedana }\end{array}$ & $\begin{array}{l}\text { Procedure Sand, heated in a pan, is } \\
\text { taken in a cloth and tied it to make a } \\
\text { pottali. This is used for swedana } \\
\text { (fomentation procedure) of Uru } \\
\text { Pradesh (thigh region) when patient } \\
\text { was suffering from intense pain. }\end{array}$ \\
\hline $\begin{array}{l}\text { Jala } \\
\text { chankramana } \\
\text { chikitsa (10)- }\end{array}$ & $\begin{array}{l}\text { Procedure-Patient was asked to walk } \\
\text { against the water current in a river for } \\
\text { about 10-15 minutes twice a day. }\end{array}$ \\
\hline $\begin{array}{l}\text { Diagnostic } \\
\text { method }\end{array}$ & As per madhav nidana (5) \\
\hline
\end{tabular}

The hetu (causative factors) done by patient like kaphakara ahar (diet increasing kapha) and vihar (activity which increase kapha) which have gave rise to ama (indisgested part of digestion) which have obstructed karya (action) of vata in uru pradesh (thigh region) of the patient giving rise to stambha (stifness) and shula (pain) in uru pradesh of patient.

\section{Case report}

A 39 years aged male businessman and owner of cold storage reported to Shree Gajanan Ayurvedic Chikitsalay \& Panchakarma center, Panvel, Navi Mumbai, Maharashtra (Registration no- 2166) with following sets of complaints-

\section{C/O-}

- Bilateral pain \& stiffness in thigh region since 2 years

- Bilateral pain in knee joints since 3-4 months

- Back pain since 6 years

- Lower back pain since 2 years

- Pain in left greater toe since few days
2 years back patient suffered from same complaint but was relieved with Ayurved treatment details not mentioned for treatment.

1. Baddha koshtata (constipation) since 15-20 years.

2. Frothy stool and pain before defecation since 2 years.

Personal history of patient revealed that patient was the owner of cold storage he use to walk every day in temperature difference of -15 degrees to 25 degrees without any necessary precautions which can be explained as virrudha hetu sevan by patient in lifestyle.

\section{$\mathbf{H} / \mathbf{O}$}

- Malaria- 15 years back

- Jaundice- 16 years back

- Skin disease- no details received

- Shitapitta (urticaria)- 3 years back

Past history of illness suggest that there was already rasa, rakta dushti (vitiation of blood and lymphatic system) in patient which may have cause the avrodh (obstruction) of medadhatu (fatty tissue) to prakruta vaata karya (normal function of vata) in uru pradeshi (thigh region)

\section{On Examination}

Naadi pareeksha (pulse examination) found the vata pradhanta of doshas with pulse rate as $76 / \mathrm{min}$. Mala preeksha (stool examination) there was saamata (indigestion) reported as patient reported sinking of the stools in water during defaecation with bad odour (suggest of incomplete digestion). Mutra pareekshan (urine examination) patient didn't report any of complaint. In jivha pareekshana (tongue examination) whitish thrush was observed centrally with bad breath. sthanik pareeksha (local examination of thigh) tenderness (pain) was observed on palpation locally. Udara pareekshana (abdominal palpation) was done and yakruta pradeshi shula (pain in right hypochondrium) was observed on palpation. Agni pareekshana (digestive examination) reported by patient as vishama (uneven) as he was not getting proper appetite regularly and he was only having meals as per protocol for time and quantity with or without hunger. Koshta pareekshana (bowel examination) madhyama koshta (medium) was reported by patient as he was having bowels well daily twice and not having any type of constipation.

\section{Treatment (Chikitsa)}

As per charak chikitsa adhyaya 27/30,31,32 Treatment given included-

\section{Medicine A}

- Musta choorna (Cyperus rotundus L.) $1.5 \mathrm{gm}$

- Lodhra (Symplocos recemosa Roxb.) $1.5 \mathrm{gm}$

- Pippali (Piper longum L.) $1.5 \mathrm{gm}$

- Pippalimoola (Piper longum L.) $1.5 \mathrm{gm}$

- Devdaru (Cedrus deodara (Roxb.) G.Don) 1.5gm 
- Vishama Jwara yog $1.5 \mathrm{gm}$ \{Combination of Kiratatikta (Swertia chirata (Wall.) C. B. Clarke), Amruta (Tinospora cordifolia (Thunb.) Miers), Chandana (Santalum album L.), shunthi (Zingiber officinale Roscoe)\}. It was used as this combination can be used as meda dhatu pachana. (ref- Ashtanga hrudaya chikitsa sthana adhyay $1 / 50$ )

- Shilajeet vati $125 \mathrm{mg} /$ dose (product of Bhradwaaj Pharmacy)

- Mahayogaraaj guggul (12) 1 tablet/dose (product of Dhootpapeshwar pharmacy)

- Brihat vaat chintamani rasa (11) $125 \mathrm{mg} / \mathrm{dose}$ (product of Baidyanath pharmacy)

All mentioned tablets were mixed with all ingredient in mentioned amount in choorna form by us. Anupana- With honey+jala / gomutra + ushna jala. Both anupana were used, initially 8 week we gave medicines with honey+jala and then we started with gomutra+jala as anupana which gave good result for meda pachana. Note: All medicines mentioned above are mixed together in given amount and equal amount of dose is given thrice from the total amount of medicines per day.

\section{Medicine B}

- Shankha vati- $125 \mathrm{mg}$ tab /dose

- Gandharvaharitaki choorna 500mg tab/dose

Anupana (medium of medicine)- With ushnodaka (hot water) after meals BD daily.

Sthanik Upchar (localised treatment)-

Sthanik ruksha swedana (local dry foementation) with hot water bag as and when pain aggrevates.

\section{Properties of medicines-}

- Shankha vati- used as a vatanulomak (forcing vata in right direction) and pachnartha (7) (promoting digestion)

- Gandharva haritaki- sreshtha vatashamak (chief to decrease vata) and vatanulomak (forcing vata in right direction)

- Mahayogaraaj guggulu- vatanashak, (decrease vata) amapachak (facilitates digestion of indigested food particles)

- Gomutra- lekhaniya (scraping action), works on meda dhatu due to laghu (light) \& ruksha (dry) quality.

- Jwara yog- includes combination of 4 choorna 1)kiratatikta 2)raktachandan 3) gulvel 4)shunthi

- Gomutra and honey both does lekhana karma (scraping action) but gomutra also acts vedanasthapana (management of pain) due to vatashamak guna (decrease vata qualities)

\section{Vihara}

- The most important thing that the patient was asked to swim and jala chankraman (walking in water) against jala pravaha (waterflow) (4). This was followed till we completed the treatment of patient. Later patient was asked to gradually reduced the swimming and finally stopped it after 2 months after complete treatment.

Good improvement was observed in pain and stiffness when patient started swimming along with abhyantara chikitsa (internal treatment). But episodes of Urustambha (stiffness of thigh region) and Uru shula (pain in thigh region) were aggravating whenever patient missed swimming, but it was still very less compared to his previous intensity before starting treatment.

Table no:1: Showing the properties of the drugs used

\begin{tabular}{|l|l|l|l|l|l|}
\hline $\begin{array}{l}\text { Name of } \\
\text { the Drug }\end{array}$ & Rasa & Virya & Vipaka & Guna & Karma \\
\hline Mustaka & $\begin{array}{l}\text { Tikta } \\
\text { Kashaya } \\
\text { Katu }\end{array}$ & Shita & Katu & $\begin{array}{l}\text { Laghu } \\
\text { Ruksha }\end{array}$ & Lekhana \\
\hline Lodhra & $\begin{array}{l}\text { Tikta } \\
\text { Kashaya }\end{array}$ & Shita & Katu & $\begin{array}{l}\text { Laghu } \\
\text { Ruksha }\end{array}$ & Lekhana \\
\hline Pippali & Katu & Ushna & Madhura & $\begin{array}{l}\text { Laghu } \\
\text { Snigdha }\end{array}$ & Lekhana \\
\hline Pippali & Katu & Ushna & Katu & $\begin{array}{l}\text { Laghu } \\
\text { Ruksha }\end{array}$ & Lekhana \\
\hline Devadaru & $\begin{array}{l}\text { Tikta } \\
\text { Kashaya } \\
\text { Katu }\end{array}$ & Ushna & Katu & $\begin{array}{l}\text { Laghu } \\
\text { Ruksha }\end{array}$ & Lekhana \\
\hline Shilajeet & Tikta & Ushna & Katu & $\begin{array}{l}\text { Laghu } \\
\text { Ruksha }\end{array}$ & Lekhana \\
\hline Haritaki & Pancharas & Ushna & Madhura & $\begin{array}{l}\text { Laghu } \\
\text { Ruksha }\end{array}$ & Lekhana \\
\hline
\end{tabular}

\section{Ahara}

Langhan (fasting) also was given whenever patient complained of kshudha mandya (low appetite)

In langhana chikitsa (fasting) just drava ahara (liquid diet) like yusha, lajamanda etc was advised with progressive improvement of food intake day by day as mentioned in sansarjana karma (diet schedule). Medicines were continued with same mentioned pattern during the langhan chikitsa.

\section{Details of Drugs used for treatment}

All the below used drugs are having katu (pungent), tikta (bitter) pradhan rasa (dominant taste) with majority having ushna virya (hot potency) which tends to work on medha dhatu with its lekhana (scraping) properties as mentioned (6). Due to these dravya (substance), medavrodh (obstruction by fat) of vata in urupradesh reduced with prakruta gati (normal movement) of vata and its functions with improvement in patient. 


\section{Observation}

\section{Subjective criteria}

A numerical rating scale (global Stanford pain scale) to describing pain mentioned by patient during the course of treatment for urustambha.

\section{Sr No. Date of follow up}

$\begin{array}{ccc}\text { 1) } & 31 / 5 / 2013 & 10 \text { units } \\ \text { 2) } & 10 / 6 / 2013 & 8 \text { units } \\ 3) & 25 / 6 / 2013 & 7 \text { units } \\ \text { 4) } & 14 / 8 / 2013 & 7 \text { units } \\ \text { 5) } & 4 / 9 / 2013 & 6 \text { units } \\ 6) & 20 / 9 / 2013 & 5 \text { units } \\ 7) & 26 / 10 / 2013 & 5 \text { units } \\ 8) & 22 / 11 / 2013 & 3 \text { units } \\ \text { 9) } & 1 / 2 / 2014 & 2 \text { units } \\ \text { 10) } & 1 / 3 / 2014 & 0 \text { units }\end{array}$

Patient was interrogated each time at the follow up by us to mention the unit for pain according to the Stanford pain scale and there was considerable dropping of pain seen after gradual treatment course

\begin{tabular}{|c|c|}
\hline \multicolumn{2}{|c|}{ Gradation of pain as per Stanford pain scale ( 8} \\
\hline Units & Gradation meaning \\
\hline 10 & Unimaginable unspeakable \\
\hline 9 & Excruciating unbearable \\
\hline 8 & Utterly horrible \\
\hline 7 & Very intense \\
\hline 6 & Intense \\
\hline 5 & Very distressing \\
\hline 4 & Distressing \\
\hline 3 & Tolerable \\
\hline 2 & Discomforting \\
\hline 1 & Very mild \\
\hline 0 & No pain \\
\hline
\end{tabular}

\section{Objective criteria}

Walking time, walking distance, SLR test (9)

(Before treatment)

\begin{tabular}{ll}
\hline Objective criteria & Gradation \\
Walking distance & $\begin{array}{l}\text { 7-10 min for 100steps } \\
\text { severe pain after walking }\end{array}$ \\
Walking distance & $\begin{array}{l}\text { 100 meters } \\
\text { Positive in both legs with 45 } \\
\text { degree }\end{array}$ \\
\hline
\end{tabular}

\section{(After treatment)}

\begin{tabular}{|cc|}
\hline Objective criteria & Gradation \\
Walking distance & 3 min for 100steps \\
& Walking without pain \\
Walking distance & 500 meters \\
SLR & Negative \\
\hline
\end{tabular}

\section{Discussion}

Pain is the factor created by obstructed or aggrevated vata at the sight of pain. This disease is caused by obstruction of fatty tissue in uru pradesh to normal functioning of vata. Hence to treat the condition we need to remove the obstruction with medo vilayan (fat burning) with lekhaniya dravya (antilipidimic drugs) with abhyantar chikitsa. (internal treatment).

The medicines used like shilajeet vati, medopachak, gomutra, mahayograj guggulu, musta choorna, pippalimoola choorna and devadaru choorna have worked on meda dhatu by removing the obstruction with its scraping properties with bringing back normal functioning of vata by reducing pain in patient.

This is the only vata vyadhi (type of disease) which is not improved by basti chikitsa (type of treatment) in panchakarma therapy which is main chikitsa (treatment) mentioned for vata rog in ayurved.

Jalachankrama chikitsa- (10)

Jalachankrmana chikitsa (walking in water) is mentioned by charak in charaksamhita is the specialize chikitsa which relieves obstruction of meda dhatu (fatty tissue) in uru pradesh (thigh region) facilitating normal functioning of vata.

Walking against the water flow does the lekhana ( scraping action) of meda dhatu (fatty tissue) in uru pradesh internally due to vyayama (exercise) in water flow.

\section{Conclusion}

Thus we can conclude Urusthambha vyadhi is a rare vyadhi (disease) found these days and is only curable with ayurvedic shaman aushadhis (internal medicines) as mentioned in samhitas. Any of panchakarma is not at all useful for any patient of urusthambha as mentioned in charak samhita. Jalachankrama chikitsa quoted by charak is very useful for vilayan of sanchit medha dhatu (accumulated fatty tissue) in uru pradeshi (thigh region) which will facilitate prakruta gati of avrutta vata ( normal functioning of obstructed vata).

\section{References}

1. Upendra Dixit. Ayurvedic approach of urusthambha a case study (Acute Transverse myelopathy, Brown Sequard syndrome with demyelinating process). JSAP. 27 may 2014; Page no.29-34

2. Mamidi Prasad and Gupta Kshama. "Urustambha"Aortoiliac acclusion with metabolic syndrome? international journal of green pharmacy, Jan-Mar 2017; Page 49-60 
3. Sharma, a. and Sharma, a. (2006). Sushuruta Samhita, Urusthambhachikitsa Adhyaya 5. Varanasi: Chaukhamba publictions.

4. Tripathi Ravidatt and, Sharma Priyavrat. Charak samhita 2 by drudabala.varanasi; Chaukhamba publications; 2006.Urustambhachikitsa adhyaya 27/59. Page 930

5. Upadhyaya Yadunandan, Madhava Nidana part-1 by Shreekanthadatt. Varanasi: Chaukhamba publications, page 457 .

6. Shastri JLN, Dravyaguna Vijnana:2nd edition, chaukhamba orientalia; 2005.

7. Gune V. Ayurvediya Aushadhigunadharmashastra. 3rd ed. Pune: Modern book depot; 2005.
8. Available from: https://www.affirmhealth.com/blog/ pain-scales-from-faces-to-numbers-andeverywhere-in-between. [cited 15 January 2020].

9. Maheshwari J. Essential orthopaedics.11th ed.,New Delhi: Mehta publishers; 2006. Page 230.

10. Priyavrat Sharma. Charak Samhita of Agnivesha. Varanasi: Chaukhama sanskrit pratishthan; 2013. Page 930.

11. Siddhinandan Mishra. Baishajya Ratnavali of Kaviraj Govindas Sen. Varanasi: Chaukhamba surbharati prakashan; 2005. Page 530.

12. Gune g. Ayurvediya Aushadhigunadharmashastra. Pune: Vaidyak grantha bhandar; 2011.

13. Ganesh Garde. Sartha Vaghbhat by Acharya Vaghbhat. Pune. Pressograph publication. 2009. Page 220 . 